DOI: https://doi.org/10.15407/techned2018.04 $: 131$

\title{
SYNTHESIS AND ANALYSIS OF MODAL CONTROL SYSTEM FOR CRANE MECHANISM MOTION TAKING INTO ACCOUNT THE WORK OF LIFTING MECHANISM
}

Journal

Publisher

ISSN

Issue

Pages
Tekhnichna elektrodynamika

Institute of Electrodynamics National Academy of Science of Ukraine 1607-7970 (print), 2218-1903 (online)

No 4, 2018 (July/August)

$131-134$

\section{Authors}

\section{O.I. Tolochko ${ }^{1 *}$, A.M. Ryzhkov ${ }^{2 * *}$}

1 - Sikorski Kyiv Polytechnic institute,

pr. Peremohy, 37, Kyiv, 03056, Ukraine,

e-mail: tolochko.ola@gmail.com

2 - Institute of Electrodynamics National Academy of Sciences of Ukraine,

pr. Peremohy, 56, Kyiv, 03057, Ukraine,

e-mail: o_ryzh@ied.org.ua

* ORCID ID : http://orcid.org/0000-0002-6871-0653

** ORCID ID : http://orcid.org/0000-0002-0011-9402

\section{Abstract}

The control system for crane mechanism with feedback over full order state vector is synthesized. This system applied to motions of crane mechanism with load suspended on a flexible rope. In addition, this system taking into account changes of rope length of lifting mechanism when it working. The Luenberger-observer was synthesized for estimation swing 
angle and angular speed of this movement. Analysis of designed modal control system was performed with mathematical modelling method. References 4, figures 5.

Key words: modal control, crane, lifting mechanism, Luenberger observer.

Received: 02.03 .2018

Accepted: 12.04.2018

Published:

\section{References}

1. Chang C.Y. The switching algorithm for the control of overhead crane. Neural Computing \& Applications . 2006.

Vol. 15. Pp. 350-358. DOI:

https://doi.org/10.1007/s00521-006-0036-z

2. Buch A. Optimale Bewegungssteuerung von schwingungsfahigen mechatronischen Systemen mit zwei Freiheitsgraden am Beispiel eines Krans mit Pendelnder Last und elastischer Mechanik. Magdeburg, 1999. 250 p.

3. Moustafa K.A.F. Feedback control of overhead cranes swing with variable rope length. American Control Conf

. Baltimor, Mariland, 1994. Pp. 691-695. DOI:

https://doi.org/10.1109/ACC.1994.751828

4. Park H., Chwa D., Hong K.-S. A feedback linearization control of container cranes: varying rope length. International Journal of Control, Automation, and System. 2007. Vol. 5. No 4. Pp. 379-387. 


\section{PDF}

